\title{
The Image of A "Good" English Teacher in College
}

\author{
Hua Yin ${ }^{1, a}$ \\ ${ }^{1}$ School of Foreign Language, Yangtze University, Jingzhou, Hubei, P. R. China \\ a2721912976@qq.com
}

\begin{abstract}
Keywords: A Good Teacher, English Teacher in College
\end{abstract}
\begin{abstract}
In colleges, being a "good" teacher, especially a "good" English teacher can lead their career till the end of life.Good communicable English is the high standard requirement for college. As a teacher, we must highly value and research it further in developing good English speaking skills.
\end{abstract}

\section{Introduction}

It's easy to be a teacher, but being a good teacher is difficult. Such a simple word "good", while the connotation is rich. Good teacher should be hard working and dedicated to their work, should care and love their student and be responsible earnestly help to set up scientific world outlook, philosophy of life and values. Also good teachers should have profound knowledge, especially the professional knowledge, psychology and pedagogy knowledge[1]. Teachers with good academic skill can provide various knowledge regarding art of teaching to the students. In the meantime,students can achieve more knowledge which helps to generate and develop intelligence in the college and society. For students at any age, good image of teachers and student-teacher relationships is helpful in the implementation of education effectively at different levels. In elementary school, good teachers are like parents. In middle school, good teachers are like friend. While in universities, good teachers are like scholar . English teachers are also without exception.

College graduates' capability of practical English doesnot meet the need of social development.Realizing this disadvantage of cramming education, English teachers have put forward the course of CET4 and CET6 to enhance students English. Implementing communicative approach step by step, organizing teaching based on student-centered, promoting language skills and developing their communication ability.

\section{Teachers are to Help Students but not to Maintain Discipline}

Teachers are the center of discipline. Knowledge of the teacher should be extensive and profound especially in professional field and also with a strong practical ability of using English. So in the process of teaching, their mind should not be puzzled while teaching. Teachers should be aware of the difficulty and the familiarity of the teaching material. Teacher should care about the psychologystate of students and provide good guidance which help students for better understanding. Especially when students encounter difficulties, as a teacher should know that the college students are first researchers and thinkers in the learning process. Their abstract thinking ability and dialectical thinking ability have already developed to a certain level. Mechanical memorizing knowledge and established conclusion will only inhibit the students' normal development of thinking ability. Sometimes it is necessary for teachers to set some problems to let the students overcome these difficulties independently. Teachers must trust students which can 
make students believe in themselves[2]. But believing in students that doesn't mean let them do whatever they want. Teachers' teaching schedule have increased, only way to get free time is to enroll students in simple works which they can perform correctly. This kind of creative work together with student will help them to be much more active and independent in the futures.

\section{Independent from the Confidence}

Psychologists have found that people's confidence comes from two aspects: one is the evaluation from others, the other is success. The higher evaluation is a kind of affirmation and encouragement. Encourage makes people work harder, thus make a certain progress. Progress is a success in some sense, and teachers should make every student often have a feeling of success.

Some students basic foundation of knowledge is weak, which should be corrected by the teachers. some students have difficulties in understanding the concept of education which makes them unhappy. While some student have behavioral problems that teacher should cooperate and understand and help to deal with the problem. Psychological councelling can be much helpful in regarding this kind of condition in students.

\section{The Combination of Direct Interest and Indirect Interest}

“Interest is the best teacher". It is necessary to study and stimulate students' interest. Cognitive interest is the most realistic and active psychological factor in motivation. Learning motivation refers to an intrinsic motivation in learning activities. Cognitive interests include direct interest and indirect interest. Direct interest can be caused by teachers' teaching art, indirect interest is closely related to the degree of learners' conscious learning. The former can be thought as the result of the emotional effect, while the latter is the individual requires himself to a high-standard level after realizing the significance of social learning. When he studies to a certain level, he'll have wonderful interests infinitely. Indirect interest requires teachers to persuade and inspect earnestly, patiently and powerfully. Direct interest requires the teachers to teach attentively for every class. Honestly, teaching well in every class is a "good" teacher's basic skill. At least it includes using class time efficiently and maximally, setting up the problems scientifically, according to different teaching content to adjust the tone and the classroom atmosphere, and even how to use the blackboard to highlight the key point to attract students' attention. A “good” teacher can both be a good actor and a good director. A "good" teacher is rich in emotion, and will always control the discretion of introversion and extroversion in personality[3]. A "good" English teacher not only make the class lively and active, and make students have tangible results. In class, methods like giving examples, discussion and writing and so on are given to increase students' awareness of the times and the patriotic sense, to clarify some misunderstandings about the society. A "good” teacher is loved and respected by students. The good political quality, noble moral sentiment and profound knowledge background and great accomplishments of a "good" teacher will become a standard model to benefit students in the long-term. The students' special feelings to the "good" teacher will changed into a powerful learning motivation and learn more and more. A keen interest is developed.

\section{Teaching Manner and Teaching Method are Equally Important}

Teachers should understand and fully believe that college students' abstract thinking, dialectical thinking and logical memory and meaningful memorization abilities have developed a lot. Knowledge is gold, method is the golden touch. English learning methods include how to understand the characteristics and relations of listening, speaking, reading, writing, translation and 
other aspects, how to make a preparation before class, learning in class and review after class, and how to overcome listening and vocabulary, especially the oral and written application of English.

With the development of college students self-consciousness level, they have developed strong sence of self design and self improvement. Learning attitude can reflect a person's character. Successful person can lead a healthy life and can gain success in their work too. As a college student should have following mantalities :ambition, confidence, patience, persistence and self discipline. These mentalities brings right attitude. Student should study step by step with their plan to achieve long term goals.

\section{The Students' Ability is Important than Score, Teachers' Long-term Consciousness is Important than Short-Term}

Currently, in colleges and universities, the main approach to examine college students' English level is still CET4 and CET6. In a sense, it can not fully reflect the extent of the students who have mastered this language, not even scientifically reflect the students' ability of practical use of English. In the future, the university graduates using English is in a real society rather than theory. The society needs their ability not score[4]. As a teacher should better understand short-term behavior in education is one of the most dangerous enemy for sustainable development. .His teaching purpose is not to train students' ability in the test, but for society, for the future, for the students' background knowledge, intelligence and life. We can see his ideological level when there is a conflict between a teacher's immediate interests and long-term interests of the students. A "good" teacher always obeys the latter completely and thoroughly without hesitation.

\section{The Second Class and the First Class are Equally Important}

Facing the 21st century, education is reforming in talent cultivation mode, focusing on cultivating inter-disciplinary talent. College English teachers should work harder in training students' language and culture quality. Basically providing good care, careful supervision and participate in the second class with students actively. In order to develop students' selection and evaluation ability in culture, and to cultivate their moral sentiment and civilization accomplishment, English teachers can recommend some ideological, knowledgeable and interesting English readings or audiovisual products, and launch work analysis meeting or musical appreciation activities. In order to develop the students' interests and special skills to enrich their after-school life, we can also help to organize speech competition, singing competition, debate competition, English drama performance, etc[5]. The teacher can shorten the psychological distance with the student in second class. In getting along with students all-round and through the observation and the understanding of students comprehensively and thoroughly, teachers can become a person that students always want to get close.

\section{Teachers' self education is more important than education}

Higher education is changed from "front-end mode" to "lifelong education" in terms of time and space reconstruction and renewal. As college teachers, especially the English teachers should consider himself as a student of doing lifelong self-education, always keep the curiosity of children and the acumen of youth, and have an open attitude toward information, learn from anywhere, from any person, from every class, and learn modestly, continuously to make himself engaged in professional fields and become an expert in related areas and even scientists, and also an education artist. 


\section{References}

[1]L. Thomas and C. Beauchamp. Understanding new teacher's professional identities through metaphor, Teaching and Teacher Education,2011, pp. 25.

[2] J.M.Guo. English teachers' image innovation and establish a new relationship between teachers and students. Journal of Hebei Radio \& TV University, 2006, pp. 31. (in Chinese)

[3] H.Z.Wang. Student-centered Teaching Mode and Communication Ability Training. Foreign Language Teaching and Research, 2001, pp. 36. (in Chinese)

[4] X.N.Liu. The Quality of Teachers in the Implementation of New Curriculum Reform. Ningxia Education, 2006, pp. 18. (in Chinese)

[5] F. Zhang. The Influence of College English Teachers' Quality in Teaching. Journal of Heilongjiang Institute of Teaching, 2006, pp. 147. (in Chinese) 